Michalina Janaszak

Uniwersytet im. Adama Mickiewicza w Poznaniu

Instytut Antropologii i Etnologii

Zakład Etnologii

\title{
Społeczna percepcja archeologii na przykładzie Rezerwatu Archeologicznego w Krzemionkach Opatowskich, red. Katarzyna Marciniak, Przestrzeń Wyobrażona, Poznań 2018, ss. 152
}

Książka Społeczna percepcja archeologii na przykładzie Rezerwatu Archeologicznego w Krzemionkach Opatowskich to praca zbiorowa przygotowana pod redakcją Katarzyny Marciniak. Publikacja jest poświęcona zagadnieniu społecznego postrzegania archeologii, który to problem przedstawiono na przykładzie funkcjonowania rezerwatu archeologicznego znajdującego się w pobliżu Ostrowca Świętokrzyskiego (case study). Rozważania prowadzone są z perspektywy etnologicznej.

Praca składa się z siedmiu artykułów oraz wstępu, którego autorką jest dr hab. prof. UAM Katarzyna Marciniak. Wprowadzając czytelnika w tematykę książki, redaktorka wyjaśnia przyczyny wyboru miejsca badań oraz przedstawia sposób ich prowadzenia. Wskazuje także podstawowe pytania badawcze, dotyczące zależności pomiędzy dziedzictwem (w omawianym przypadku chodzi o neolityczne kopalnie krzemienia pasiastego) a miejscową społecznością: „czy bliskość stanowiska archeologicznego wpływa na archeologiczną wiedzę mieszkańców, w jaki sposób samo stanowisko odbierane jest przez miejscową ludność, czy jest dla nich czymś ważnym, czy identyfikują się z tym miejscem i czy (i ewentualnie, w jaki sposób) sąsiedztwo takiego 
rezerwatu wpływa na życie mieszkańców okolicznych wsi. Interesowało nas również stanowisko władz miejscowych, w jaki sposób widzą rozwój tego miejsca i jego wpływ na ewentualny rozwój regionu” (Wstęp, s. 6.).

Obszar badawczy był stosunkowo rozległy, obejmował bowiem także wsie położone w pobliżu rezerwatu. Szerokie ujęcie tematu wymagało ponadto przeprowadzenia badań porównawczych, do których materiał pozyskano w miejscowości Piwniczna-Zdrój. W toku prac zainteresowanie badaczy skupiło się także na znajdującym się w Bałtowie parku rozrywki „Jura Park”.

Pierwszym z siedmiu zamieszczonych w publikacji artykułów jest tekst Sławomira Toczka zatytułowany Ochrona, zarzadzanie i znaczenie rezerwatu archeologicznego w Krzemionkach. Autor w skrótowy sposób przedstawia w nim historię miejsca (nawiązując do czasów neolitu), a następnie przechodzi do opisu działań mających na celu jego ochronę. Kolejna część artykułu to rozważania dotyczące funkcjonowania rezerwatu; jego powiązań ze społecznością lokalną, odbioru społecznego, rozpoznawalności i ruchu turystycznego.

W artykule Przemysława Jankowskiego zatytułowanym Strategie i skuteczność komunikacji online polskich muzeów archeologicznych ze szczególnym uwzględnieniem Muzeum Archeologicznego i Rezerwatu „Krzemionki Opatowskie" poruszono kwestie związane z bardzo aktualnym i ważnym zagadnieniem - wykorzystywaniem nowych technologii (a konkretnie aktywnością w internecie) w budowaniu pozycji instytucji oraz jako narzędzia komunikacji z odbiorcami. Analizie porównawczej poddano kilka instytucji muzealnych, uwzględniając sposób ich funkcjonowania w cyberprzestrzeni. Autor przedstawił także propozycje wprowadzenia zmian w przejawach tejże aktywności, które mogłyby — jego zdaniem przynieść pozytywne efekty.

W tekście Percepcja dziedzictwa archeologicznego wśród uczniów szkót Ostrowca Świętokrzyskiego i Piwnicznej-Zdroju autorka - Joanna Dworzecka - przedstawia wyniki badań przeprowadzonych wśród gimnazjalistów. Kierowane do ankietowanych pytania miały pomóc badaczom w ustaleniu stopnia zainteresowania uczniów lokalnym dziedzictwem archeologicznym oraz poziomu ich wiedzy na ten temat.

Izabella Wenska poświęciła swój tekst, zatytułowany Krzemionki i Battów - dwie wizje atrakcji turystycznej, problematyce związanej z ruchem turystycznym. Autorka porównała dwa obiekty o odmiennych profilach, 
które w swej działalności nawiązują, bezpośrednio lub pośrednio, do przeszłości miejsca i związanego z nim dziedzictwa.

W drugim artykule autorstwa Sławomira Toczka, zatytułowanym Rezerwat archeologiczny $w$ Krzemionkach. Perspektywa pamięci społecznej, autor poświęca wiele uwagi funkcjonowaniu muzeum i rezerwatu oraz interakcji zachodzącej pomiędzy nimi a mieszkańcami. Do działań związanych z edukacją ekologiczną i wykorzystaniem przyrodniczych walorów miejsca nawiązała Agata Ożarowska w tekście Perspektywy wykorzystania walorów przyrodniczych Rezerwatu Krzemionki Opatowskie jako przykład rozwijania świadomej edukacji ekologicznej w świetle zrównoważonego rozwoju. Książkę zamyka artykuł pt. Rezerwat Archeologiczny „Krzemionki Opatowskie” z perspektywy prasy i internetu, autorstwa Ludwiki Wachowicz-Moczarskiej.

Omawiana praca została oparta na interesującym materiale badawczym, a jej przygotowanie poprzedziła gruntowna analiza funkcjonowania działalności rezerwatu „Krzemionki” oraz powiązanego z nim muzeum. Rozważania autorów koncentrują się wokół dziedzictwa archeologicznego, jednak wydaje się, że wiele spośród omawianych zjawisk można odnieść do percepcji dziedzictwa jako takiego. Uniwersalna jest zwłaszcza problematyka związana z funkcjonowaniem instytucji kultury w cyberprzestrzeni oraz mediach, a także zagadnienia dotyczące pamięci społecznej czy edukacji ekologicznej. Wszystkie te kwestie pojawiają się we współczesnej muzeologicznej refleksji. Również omawiany w kilku miejscach fenomen „Jura Parku” może być rozpatrywany w powyższych kategoriach. Jako element wielozmysłowego poznania, o którym pisze w swym tekście Izabella Wenska (s. 93-94), staje się sposobem swoistej animacji przekazu muzealnego. Chociaż tematycznie niezwiązany z historią neolitycznych kopalń, nastawiony na rozrywkę i realizujący inne niż rezerwat czy muzeum cele, w świadomości wielu zwiedzających w jakiś sposób się z nimi wiąże. Jak słusznie zauważa we wstępie redaktorka, turyści szukają w nim bowiem także wiedzy o przeszłości: „W obu miejscach przeszłość została zmaterializowana. Oczywiście można się oburzyć, stwierdzając, iż Bałtów jest kreacją wyobraźni na temat naszej wizji rozwoju geologicznego regionu, artefakty, które tam się znajdują nie są prawdziwe (...), lecz w Krzemionkach znajdujemy dokładnie podobne zabiegi: poszerzone chodniki pomiędzy poszczególnymi jamami wyrobiskowymi czy też postacie skulonych neolitycznych górników, które w tych jamach zostały umieszczone, są takimi samymi symulakrami jak 
dinozaury w bałtowskim parku rozrywki” (Wstęp, s. 6-7). Szczególnie interesujące, zarówno z perspektywy etnologicznej jak i muzeologicznej, są relacje zachodzące pomiędzy dziedzictwem i chroniącą je instytucją kultury a społecznością lokalną. Sławomir Toczek w tekście dotyczącym pamięci społecznej nawiązuje do procesu przesiedlania mieszkańców wsi Krzemionki, na miejscu której powstał rezerwat archeologiczny, jak również do ograniczenia mieszkańcom okolicznych miejscowości dostępu do lasu (w związku z powstaniem rezerwatu przyrodniczego) (s. 108-111). Społeczny odbiór tych wydarzeń oraz związana z nimi dychotomia swój-obcy rzutują na percepcję lokalnego dziedzictwa, są zatem niezwykle istotnym elementem rozważań autorów.

Relacje zachodzące pomiędzy instytucjonalnie chronionym dziedzictwem a „odbiorcami”, przedstawicielami lokalnej społeczności, to zagadnienie wiążące się z problemem partycypacji społecznej w instytucjach kultury. W tym aspekcie pożądane byłoby poszerzenie rozważań o perspektywę muzealną. Niestety, w książce zabrakło głosu muzealników.

Poszczególne artykuły prezentują ciekawe spojrzenie na zagadnienia związane ze społecznym odbiorem dziedzictwa archeologicznego. Zebrany przez autorów materiał badawczy został poddany rzetelnej analizie, co czyni pracę wartościową i godną polecenia pozycją, szczególnie dla tych, którzy interesują się problematyką dziedzictwa (naturalnego i kulturowego). Relacja zachodząca pomiędzy dziedzictwem a społecznością nie zawsze jest łatwa; może ono bowiem stanowić powód do dumy, wyróżnik, pozostając jednocześnie tabu. Może być dostępne i ukryte; czasem (często?) ochrona i udostępnienie wiążą się z „oddaleniem”. Czy jednak dziedzictwo, będąc „wspólnym”, przestaje być „naszym”? 